Bełdowski J., Słomka-Gołębiowska A., Banking Union as an institutional response of the European Union to the financial crisis 2008-2009, „Ekonomia i Prawo. Economics and Law”, Polszakiewicz B., Boehlke J. (ed.), Vol. 15, No. 2/2016, pp. 153-165. DOI: http://dx.doi.org/10.12775/ EiP.2016.009.

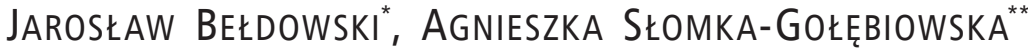

\section{BANKING UNION AS AN INSTITUTIONAL RESPONSE OF THE EUROPEAN UNION TO THE FINANCIAL CRISIS 2008-2009}

\author{
SUMMARY
}

The Banking Union, which formally commenced its operations on $4^{\text {th }}$ November 2014, is an institutional response of the European Union to the financial crisis of 2008-2009. From the institutional economics perspective it has been a breakthrough comparable to the decision on the establishment of economic and monetary union. The aim of the paper is to analyze some institutional change related to the process of integration of banking sector in the euro zone countries within the architecture of the Banking Union. The focus of the analysis is on the fit between existing institutions, to a large extent formal one meaning legal framework to a newly introduced regulations. We employ a descriptive analysis which is frequently used as the method within new institutional economics. Through scrutiny of institutional development we come to the conclusion that the banking union is not well-designed institutional scheme for potential crisis ahead. In particular, we argue about potential weaknesses of the process due to the adjustment of new framework to the existing institutional conditions. The major risks come from complexity of previous institutional

" Jarosław Bełdowski, Warsaw School of Economics, Collegium of Economic Analysis, Department of International Comparative Studies, al. Niepodległości 162, 02-554 Warszawa, Poland, phone: +48 225649 345, e-mail: jbeldo@sgh.waw.pl.

"* Agnieszka Słomka-Gołębiowska, Warsaw School of Economics, Collegium of Economic Analysis, Department of International Comparative Studies, al. Niepodległości 162, 02-554 Warszawa, Poland, phone: +48 225649 345, e-mail: aslomka@sgh.waw.pl (corresponding author). 
settings and replaying them with the new harmonized set of regulation that are accompanied this diversity of informal institutions in different Member States as well as not harmonized set of sanction system. However, we envisage that such changes are necessary in order to avoid externalities caused by complicated and overlapping institutional design of the Banking Union.

Keywords: financial crisis; Banking Union; institutional change

JEL Classification: G21; G28

\section{INTRODUCTION}

The banking system is not a static system, which is in equilibrium, but rather a system which consists of a set of institutions, changing incrementally. It means that their present shape is determined by the initial characteristics as well as small chance circumstances that can determine solutions that, once they prevail lead one to a particular path. Such dependence is defined as the path depending on past events - path dependency ${ }^{1}$. Institutional changes are the result of a series of legal and economic factors that generate new institutions, adapting existing ones which push towards the development of the entire banking system. The most important role in shaping the banking system, almost from the very beginning of its existence, are played by formal institutions - regulations. They reflect some political agenda and should therefore be treated as an endogenous variable.

The aim of the paper is to analyze some institutional change related to the process of integration of banking sector in the euro zone countries within the framework of the Banking Union, in particular with the focus on the regulations. It is attempted to assess potential weaknesses or threats that may emerge during such an adjustment process of the new institutional framework to the existing one.

The benefits of the Banking Union should be assessed primarily in the long-term horizon due to its impact on further integration of the economic and monetary system in the European Union. It is to be achieved through reduction of the transaction costs and improving the range and quality of financial services. In a consequence, it should contribute to increasing competition in the banking sector in the euro zone and harmonizing the prices of the financial services, which in turn shall result in the future consolidation. The scope and speed of these processes depend on the quality of institution-

${ }^{1}$ P. North, Institutions, Institutional change and economic performance, Cambridge University Press, Cambridge 1990, p. 94. 
al changes in the banking system stability through the creation of an effective banking supervision and resolution mechanisms and common deposit guarantee schemes in a framework of three pillars:

- Single Supervisory Mechanism (SSM) - supervision over the banking sector in the euro zone countries;

- Single Resolution Mechanism (SRM);

- Single Deposit Guarantee Scheme (SDGS).

The Banking Union is a denial of the rescue banks scenario by increasing the role of sovereigns in the euro zone countries. As a consequence of massive shifting of private liabilities to the states indebtedness, its ratios rapidly increased, leading to ratings downgrades, triggering extreme budgetary measures and massive unemployment.

Therefore, the ultimate goal of the Banking Union is to restore creditworthiness of financial markets and to reduce some public debts of the EU Member States. It may be achieved through cutting the links of the banking system debts with those of sovereigns. Additionally, more stringent banking supervision restrains moral hazard related to bank managers, shareholders and creditors as their belief that governments shall bail out insolvent banks was anchored after the crises. In consequence, the Banking Union is to offer more strict regulation for banking sector, higher capital adequacy levels and independent supervisory centralization as well as bank resolution mechanism if necessary. The moral hazard generated by the fact that a bank is too big to fail, is hence reduced and banks and their shareholders shall take that into account.

The remainder of this paper is organized as follows. Section 2, preceded by the introduction, presents the main objectives of institutional restructuring project in banking sector of euro zone countries. In the next section we analyze the new regulation and the process of institutional change related to the Banking Union. Section 3 explains the results of adjusting the new institutions to the existing framework by indicating the strengths and weaknesses of the Banking Union. In the last section, conclusions as well as implications for policy makers and regulators are drawn and presented. 


\section{INSTITUTIONAL ARCHITECTURE OF THE BANKING UNION - STATE OF KNOWLEDGE, DESCRIPTIVE METHOD AND RESEARCH PROCESS DIVIDED INTO THREE MECHANISMS}

\subsection{SINGLE SUPERVISORY MECHANISM (SSM)}

The Single Supervisory Mechanism (SSM) was introduced by the Council Regulation 1024/2013 of 15 October 2013 as a centralized model of banking supervision. However, SSM as a new institution must fit into the existing institutional framework, in particular the laws. Centralization of supervision reduces the possibility of pursuing national interests and coordination problems by minimizing home and host-country biases. It also results in more effective risk management and reduces surveillance and compliance costs. Thus centralization of supervision is regarded as enabling better functioning internal capital markets, which enhance financial stability and risk diversification. For the cross-border capital groups proper centralization of group functions, such as risk and liquidity management, leads to more efficient resource allocation with positive stabilization effects. Inadequate use of these by multinational groups may create instability, possibly spreading shocks across borders and amplifying contagion effects. In effect, integrated cross-border regulation and supervision should be in place.

The SSM is exercised by the European Central Bank (ECB), which retains responsibility for its functioning and the national supervisory authorities of the euro area. The idea of locating banking supervision in the central bank is widespread as 14 out of 19 euro zone countries follow the model ${ }^{2}$. Additionally, the only body that could intervene without a change of the law is the ECB, since the EU treaty framework - as modified by the Maastricht Treaty - already contains a provision allowing the ECB to exercise prudential responsibilities. According to the Article 127 (6) of the Treaty on the Functioning of the European Union (Treaty, TFUE): "the Council, acting by means of regulations in accordance with a special legislative procedure, may unanimously, and after consulting the European Parliament and the European Central Bank, confer specific tasks upon the European Central Bank concerning policies relating to the prudential supervision of credit institutions and other financial institutions with the exception of insurance undertakings".

The SSM will be a two-tier system, whereby the ECB supervises so called significant banks. The national supervisors continue their activities for

2 Z. Darvas, G. Wolff, Should non-euro area countries join the single supervisory mechanism?, "Danube", Vol. 4, No. 2/2013, pp. 141-163. 
the "less significant banks" but also act on behalf of the ECB and - within the overall SSM structure - may contribute to the supervision of the more significant ones. Moreover, the national supervisors will maintain their competences in fields such as prudential rulemaking as members of the EBA, as well for non-prudential matters. At least for an unspecified period of time, the SSM could be characterized by a strong element of cooperation between the ECB and the national level. In fact the role of national authorities is increased in the period of a conflict between the EBC and significant banks when they will be acting as the arbitrator. However, the duty of cooperation with national supervisors is integrated part of the SSM regime, but it is of a different nature from the previous one. Before it was horizontal, relating to supervisor standing at the same level, whereas in the SSM it is vertical and aims at ensuring the overall functioning of the SSM under the leadership of the ECB.

The SSM regime applies to banks or more precisely "credit institutions", to be understood as "an undertaking the business of which is to receive deposits or other repayable funds from the public and to grant credits for its own account". Other financial institutions are not subject to the SSM, although the Treaty, in its Article 127 (6) may allow "other financial institutions" to be included in the SSM's remit. The smaller institutions will be supervised locally but in line with guidelines that are determined by the ECB save that the latter can take over the supervision from the national supervisor. The larger credit institutions and the more risky ones - so called significant banks - are directly supervised by the ECB with some cooperation with the national supervisors. The definition of significant credit institutions that are subject to direct ECB supervision is based on three criteria: size, state support and minimal local presence. The former one is the most important criterion. A credit institution individually or where applicable group wise is considered significant if its total assets exceed 30 bln EUR or its ratio of total assets over the GDP in its participating state exceeds 20\%. Additionally, it is identified on the basis of a notification by the national supervisor as being of significant relevance to the domestic economy. The ECB should analyze the situation and confirm such significance status. Within this criterion banking groups from participating Member States are identified of "significant relevance" as having established banking subsidiaries in several participating Member States, as cross-border contagion risks may be increased in those cases. The second criteria is the existence of public support from the European Financial Stabilisation Mechanism (EFSF) or European Stability Mechanism (ESM) as the ECB supervision would be a condition for obtaining such support. Eventually the third criteria can be designated at ensuring a minimal 
ECB supervisory presence in all participating Member States. However, three most significant credit institutions in each Member State will definitely come under ECB supervision. As a result, under the direct supervision of the SSM 128 banks in the euro zone are operated, including 124 institutions relevant and 4 banks, which are one of the three largest banks in the home country ${ }^{3}$. The total value of assets of significant banks amounted to 85 percent of total banking assets and it accounted for approx. 2 per cent of the total number of financial institutions in the euro area (figure 1).

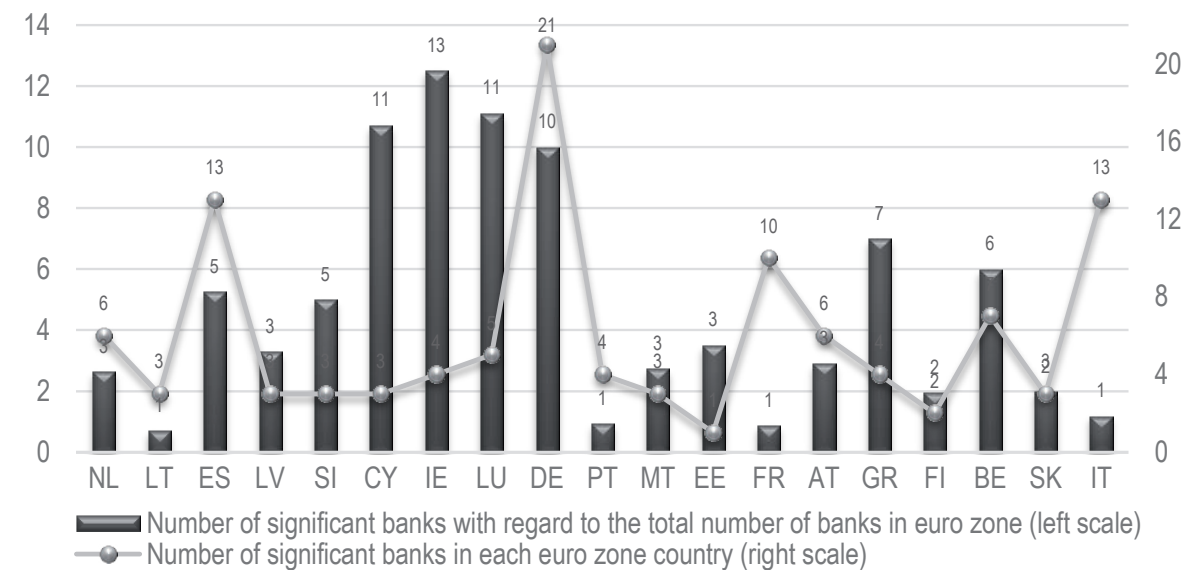

Figure 1. The number of significant banks with regard to the total number of banks in euro zone in 2014 Source: Own calculation based on data from SNL Financial, http://www.snl.com (22.04.2016).

The tasks conferred on the ECB with banking supervision function include the following:

- to authorise credit institutions and withdraw such authorisations;

- to assess applications for the acquisition and disposal of qualifying holdings in credit institutions;

- to ensure compliance with prudential requirements on credit institutions (in areas like own funds requirements, large exposure limits, liquidity, leverage, etc.) and with requirements to have in place robust governance arrangements, including "fit and proper" requirements for bank managers, risk management processes, internal control mechanisms, remuneration policies, etc.;

${ }^{3}$ E. Wymeersch, The single supervisory mechanism or "SSM", part one of the Banking Union, National Bank of Belgium Working Paper, No.255/2014. 
- to carry out supervisory reviews, including stress tests, and other supervisory tasks concerning recovery plans and early intervention.

The ECB and national competent authorities are subject to the duty of cooperation in good faith and an obligation to exchange information. National authorities are responsible for assisting the ECB with the preparation and implementation of any acts relating to the tasks conferred on the $\mathrm{ECB}$ by the regulation. Hence, the ECB as an integrating supervisor:

- exercises oversight over the functioning of the system, may at any time make use of its investigatory powers;

- requests information from the national competent authorities on the performance of the tasks carried out by them that were assigned by the EBC or are related to less significant banks.

The ECB is provided with the same powers as those available to competent supervisory authorities under the EU law. To the extent which is necessary to carry out its tasks under the new regulation, the ECB may require, by way of instructions, national authorities to make use of their powers where the regulation does not confer the same competency on the ECB. In general, the ECB's prudential supervision is primarily to ensure that banks comply with the requirements of EU directives and regulations, which means that they are conducted in a prudent, cautious and responsible way.

\subsection{SINGLE RESOLUTION MECHANISM (SRM)}

The Single Resolution Mechanism (SRM) was put into action by the Council Regulation 806/2014 of 30 July 2014 along with other instruments complementing its operation, in particular the Council implementing Regulation 2015/81 of December 2014 specifying uniform conditions of application of Regulation 806/2014 with regard to ex ante contributions to the Single Resolution Fund (SRF). One shall not also forget that within SRM framework Bank Recovery and Resolution Directive 59/2014 plays its crucial role by providing an uniform approach towards recovery and resolution among all Member States of the EU. Such resolution institutional setup is new to the euro zone area as it remained domestic in the past. It is noticeable that resolutory regime embedded within restructuring and bankruptcy proceedings started to mushroom from the Member States seriously touched upon the financial crises, e.g. the United Kingdom ${ }^{4}$. However, the cross-border banking framework and the resolutory problems which it creates led

${ }^{4}$ J. Bełdowski, D. Prokop, Koncepcja resolution regime w Unii Europejskiej i w Polsce, "Bezpieczny Bank", No. 2(44)/2011, pp. 7-47. 
to the establishment of uniform rules within the European Union. Again, apart from its establishment SRM needs to fit within already existing institutional environment, in particular Single Supervisory Mechanism, to reflect the division of tasks. However, the complicated structure of the latter as already described above may have some significant impact on the effectiveness of SRM which should be fully operational by $1^{\text {st }}$ of January 2016. In addition, SRM Regulation sets up the transitional period for the SRF to be built-up as it is envisaged that its financial contributions shall reach the target levels by January 2014 at the latest.

It shall be emphasized that the legal basis for the SRM differs from the SSM. The SRM is based on Article 114 of TFUE which allows the adoption of measures for the approximation of national provisions aiming at the establishment and functioning of the Single Market. It is also to be noted that the structure of SRF is regulated by the Intergovernment Agreement (IGA) among the participating Member States. The IGA covers the transfer of some contributions raised by the national resolution authorities to the national compartments of SRF, the mutualisation of the funds available in the national compartments and some temporary lending to name just a few.

The SRM's structure corresponds with SSM's division of power between the ECB (significant banks and cross-border groups) and national supervisory authorities. However, the SRM is to cooperate closely with national resolution authorities which may not match directly with national supervisory authorities. For instance, in case of Poland the role of domestic resolution authority is entrusted from $1^{\text {st }}$ of November 2015 to the National Guarantee Fund (pursuant to the contents of the Act on macro-prudential supervision of $5^{\text {th }}$ of August 2015 which partially implements Bank Recovery and Resolution Directive in Poland).

The key institution for SRM is the Single Resolution Board (SRB). It comprises of a Chairman, a Vice Chair and four permanent members and some relevant national authorities. Additionally, the permanent observers come from the ECB and the European Commission. The main tasks of the $\mathrm{SRB}$ are:

- to draft resolution plans for the banks under SRM (including banks under SSM and cross-border groups);

- to assess ability to resolve and to adopt resolution plans;

- to adopt resolution decisions and its tools;

- to ensure on measures of early intervention;

- to cooperate and give instructions to national resolution authorities.

The tools which may used in the resolution process include:

- sale of business; 
- bridge bank;

- asset separation;

- write down or conversion of capital instruments;

- bail-in.

The SRB operates in two sessions, namely an executive one a plenary one. The former is focused on preparatory and operational decisions of resolution process for the individual bank limited to the usage of less than 5 bln EUR from SRF as well as decisions to be taken by national authorities to implement detailed measures. The plenary session is to decide above $5 \mathrm{bln}$ EUR in accordance with draft decisions prepared by the executive plenary. But in cases with resolutions above 5 bln EUR the timeline for the plenary session is limited to three hours in order to either act or not to react. The silence on the plenary side leads to the enforcement of executive plenary's decision. Apart from individual cases plenary session may adopt guidelines to be followed by the executive session when more than 5 bln EUR of SNF are utilized over 12 rolling months. The voting power of plenary session is set up in line with the following rules:

1. decisions to use of existing means of the SNF (including transitional period) are to be adopted by simple majority representing $30 \%$ of contributions to the SNF;

2. decisions to borrow or involving ex-post contributions are to be adopted by $2 / 3$ majority representing $50 \%$ of contributions during the transition period;

3. decisions to be taken in the steady state are to be adopted by $2 / 3$ majority representing $30 \%$ contributions.

It is the duty of the ECB to inform the SRB that a bank is failing or likely to fail. However, the SRB can request such a determination of the ECB on its request and eventually the SRB can take it if there is no action by the ECB. There are three conditions to be taken into account while resolution is being decided, in particular (1) a bank is failing or likely to fail, (2) no alternative private solutions exist and (3) a resolution is in the public interest. The positive answers to those questions trigger a resolution plan to be adopted by the SRB along with use of SRF. However, the European Commission and the Council have the power to endorse or object the resolution scheme. For instance, the objection requires the SRB to amend the resolution scheme within limited time which can be extended up to 32 hours in order to resolve such a bank over the weekend ${ }^{5}$. The steps to be further taken are described

\footnotetext{
${ }^{5}$ European Court Of Auditors, Special Report European banking supervision taking shape EBA and its changing context, Luxembourg 2014.
} 
in detail in the SRM Resolution which implies cooperation among several EU institutions within specified time limits.

\subsection{SINGLE DEPOSIT GUARANTEE SCHEME (SDGS)}

From the outset it important to note that the third pillar of Banking Union - the Single Deposit Guarantee Scheme (SDGS) has been only announced recently. On 24 ${ }^{\text {th }}$ of November 2015 the European Commission brought into light the proposal to amend the Regulation 806/2014 leading towards European Deposit Insurance Scheme (EDIS) in 2024 managed by the Single Resolution and Deposit Insurance Board. The latter will be in fact an extended version SRB responsible for SRD and European Deposit Insurance Fund. In general EDIS will encompass all Member States notwithstanding the character of DGS operating domestically. They will keep their status preserving some of their functions, but they will become a part of EDIS. The process of building a new institution will be divided into some phases. In the first one re-insurance scheme will be established up to 2020 whereas in the second one it will be followed by co-insurance scheme until 2024. The evolution of EDIS in comparison with participating DGS is presented below.

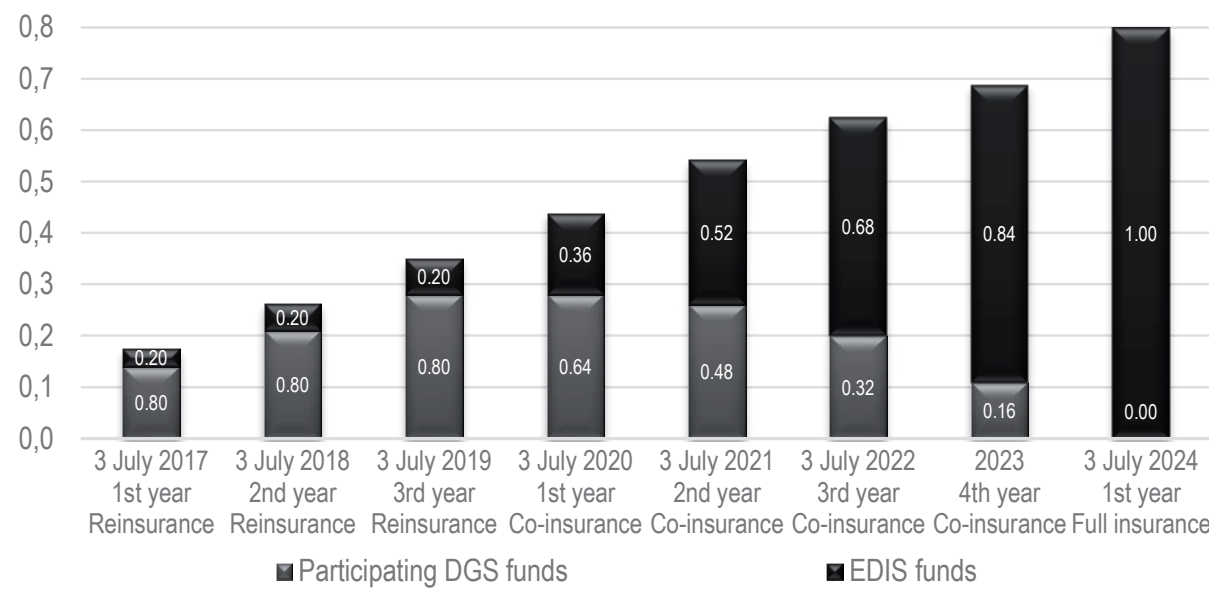

Figure 2. The evolution of EDIS in comparison with participating DGS (in \%)

Source: European Commission, http://europa.eu/rapid/press-release_MEMO-15-6153_en.htm?locale=en (22.04.2016). 


\section{STRENGTHS AND WEAKNESS OF INSTITUTIONAL FRAMEWORK OF THE SSM - RESULTS OF ANALYSIS}

The institutional change related to the establishment of the SSM regime - the longest functioning pillar of the Banking Union - may pose a number of risks which if materialize affects the ability to achieve the essential objectives of the project. SSM is a very complex formal institution, which is supplemented by informal ones such as traditions, habits, standards and practice of supervision of the individual Member States. As a result, there is a discord between the progressive harmonization of legislation relating to the euro area banking sector and the practices of the national banking supervisors. It will linger longer than generally expected, because informal institutions as argued by North - change very slowly ${ }^{6}$. Moreover, persistent differences in financial supervision in the SSM Member States, especially with regards to the sanctions for failure to comply with formal standards, may lead to unequal treatment of individual banks. Generally, enforcement of guidelines by the ECB may be difficult before the national courts and an appeal to the Court of Justice of the European Union may be very time-consuming. Alternatively, national supervisors can be asked to conduct such cases before its own courts, but it will involve agency problems between the ECB and the national supervisor. The ECB has only the power to impose sanctions on individuals who have violated EU law, and in other cases it must rely on national supervision.

Some risks also stem from the SSM's institutional complexity. In this framework, the ECB works with a wide body of organizations such as: the ESA (European Supervisory Authorities), the European Systemic Risk Board (ESRB) and national supervisors, which form the European System of Financial Supervision (ESFS), and finally with organizations appointed to carry out restructuring process: EFSF and ESM. The complexity of the institutional regime of the SSM makes transparency of banking supervision vague. In addition, the responsibilities of many organizations which are part of the supervisory system overlap. The best example is the ESRB and ECB. The former is responsible for macro-prudential supervision whereas the latter pursues micro-prudential supervision. The scope of the ESRB authorities are limited to issuing recommendations and warnings, while the ECB has some access to the full range of macro-prudential policy instruments, but also can act as a micro-prudential supervisor and to provide some support to the $\mathrm{ESRB}$, as the risk of individual banks are linked to the systemic risk.

\footnotetext{
${ }^{6}$ P. North, op. cit., p. 6, 93.
} 
Ferrarini puts some emphasis on an issue of decoupling regulation from supervision within the Banking Union ${ }^{7}$. The ECB shall adopt guidelines and recommendations, and take decisions subject to and in compliance with the relevant EU law to which all EU Member States are subject to. It shall in particular be subject to binding regulatory and implementing technical standards developed by EBA and adopted by the European Commission in accordance with the EBA regulation, and to the provisions of regulation on the European supervisory handbook developed by EBA. However, the EBC has only very limited regulatory powers with regard to prudential supervision as its all powers are related to supervision of significant banks from euro zone countries.

The SSM encompasses only the euro area countries which contributes to the institutional complexity of the European Union. Consequently, the establishment of a Banking Union leans to the existence of three groups of the EU Member States that are subject to harmonization of laws, namely participating Member States, non-participating Member States which entered the SSM under close cooperation and non-euro zone countries that have not decided to join the SSM. It will lead to the creation of different institutional settings for each of these groups, but a system of sanctions within such groups will be different. However, North notes that ineffective system of sanctions makes that institutions do not matter because people and organizations do not follow the rules of the game, which they define ${ }^{8}$. This raises all sorts of risks, e.g. regulatory arbitrage. In addition, there is some risk that limiting the SSM to the euro area Member States will contribute to "twospeed" Europe. As a result, it can lead to further fragmentation, which is exactly the opposite to the fundamental goal of the Banking Union.

\section{CONCLUSIONS}

Our starting point was to emphasize that the banking system is not a static one which is determined by the initial characteristics. In North's words it is the path depending on past events. However, the process of establishing the Banking Union within the European Union is a clear institutional response to the financial crisis which started in 2008. Even though the new institutions were created its success depends on the process of fitting into ex-

7 G. Ferrarini, Single Supervision and the Governance of Banking Markets, ECGI Working Paper, No. 294/2015.

${ }^{8}$ P. North, op. cit., pp. 68-69. 
istence framework of institutions within the European Union. As we proved the latter consists of mosaic competences of international and domestic authorities which may not contribute to the goals of Banking Union under constraint circumstances. As noted, the Banking Union sanctions enormous complexity of institutional setting similar to this observable in the United States. The managing of the relationship between all the involved parties is one of the key challenges faced by the European Commission.

The measure of success of the Banking Union project will be a significant improvement in the quality of supervision and assets of European banks and reversing the fragmentation of the financial sector. For the Single Supervisory Mechanism the biggest challenge will be to maintain a balance between centralization of supervision in the hands of the ECB and the delegation of supervisory powers to national supervisors. The relation with the ECB remains also the key issue for the second pillar of Banking Union - the Single Resolution Mechanism. The last one - European Deposit Insurance Scheme - appears to be still a bone of contention between Member States and its final fate still remains unsure.

From the European Union institutional setup it may be presumed that the existing institutional framework appears to be too complex in the beginning, but it leads to some clarification over the years. We envisage that such changes are necessary in order to avoid externalities caused by complicated and overlapping institutional design of the Banking Union.

\section{BIBLIOGRAPHY}

Bełdowski, J. Prokop D., Koncepcja resolution regime w Unii Europejskiej $i$ w Polsce, "Bezpieczny Bank", No. 2(44)/2011.

Darvas Z., Wolff G., Should non-euro area countries join the single supervisory mechanism?, "Danube", Vol. 4, No. 2/2013, http://dx.doi.org/10.2478/danb-2013-0007.

European Commission, http://europa.eu/rapid/press-release_MEMO-15-6153_ en.htm?locale=en (22.04.2016).

European Court Of Auditors, Special Report European banking supervision taking shape - EBA and its changing context, Luxembourg 2014.

Ferrarini G., Single Supervision and the Governance of Banking Markets, ECGI Working Paper, No. 294/2015, http://dx.doi.org/10.2139/ssrn.2604074.

North D., Institutions, Institutional change and economic performance, Cambridge University Press, Cambridge 1990.

SNL Financial, http://www.snl.com (22.04.2016).

Wymeersch E., The single supervisory mechanism or "SSM", part one of the Banking Union, National Bank of Belgium Working Paper, No.255/2014. 
